\title{
Inhibition of Pseudomonas aeruginosa Biofilm Formation and Quorum Sensing System by Extracts of Prunus avium Stalk
}

\author{
Prunus avium Sapından Elde Edilen Özütlerle Pseudomonas aeruginosa'ya ait Quorum \\ Sensing Sisteminin ve Biyofilm Oluşumunun İnhibisyonu
}

\author{
Ayla YILDIZ ${ }^{1}$ (i), Arhun Ali BALKAN ${ }^{1}$ (iD), Didem BERBER B $^{2,3}$ \\ Barış GÖKALSIN ${ }^{1}$ (i) , N. Cenk SESAL ${ }^{2}$ (iD \\ ${ }^{I}$ Marmara University, Institute of Pure and Applied Sciences, Biology Department, Istanbul, Turkey. \\ ${ }^{2}$ Marmara University, Faculty of Arts and Sciences, Biology Department, Istanbul, Turkey. \\ ${ }^{3}$ Maltepe University, Fine and Arts Faculty, Gastronomy and Culinary Department, Marmara Egitim \\ Koyu, İstanbul/Turkey.
}

\begin{abstract}
Recently, misuse or overuse of antibiotics has led to antibiotic resistance problem, a global healthcare problem. Most virulence factors and biofilm formation in Pseudomonas aeruginosa are controlled by quorum sensing (QS). The inhibition of QS system by inhibitor molecules has been suggested as a novel alternative antivirulence approach in which no need to kill the bacteria. In the present study, QS and biofilm inhibitory potentials of the methanol and acetone extracts of Prunus avium stalk against $P$. aeruginosa were evaluated. The extracts were tested at the concentrations of 240,120 , and $60 \mu \mathrm{g} / \mathrm{ml}$. las $B$-gfp, rhlA-gfp, $p q s A$-gfp biosensor strains and $P$. aeruginosa PAO1 were used to monitor QS and biofilm inhibition, respectively. Fluorescence and absorbance measurements were performed on Cytation 3 multimode microplate reader. QS inhibition ratios for las, rhl, and pqs systems and biofilm inhibition ratios of the acetone extracts were recorded as $70.43 \%, 47.25 \%, 76.31 \%$, and $47.76 \%$ $( \pm 6,60)$ and of the methanol extracts as $74.96 \%, 40.10 \%, 71.89 \%$, and $38.54 \%( \pm 3,56)$ at a certain concentration of $240 \mu \mathrm{g} / \mathrm{ml}$, respectively. As a result, anti-QS and anti-biofilm properties of acetone extracts were better than that of methanol extracts. Further investigations are needed to discover inhibitor compounds of $P$. avium and also their effects on human cells and then these compounds may be used in new drug discoveries.
\end{abstract}

Keywords: Pseudomonas aeruginosa, quorum sensing, biofilm, quorum quenching, Prunus avium stalk, sweet cherry.

\section{$\ddot{O} z$}

Son zamanlarda, antibiyotiklerin yanlış veya aşırı kullanımı, küresel bir sağlık sorunu olan antibiyotik direnci sorununa yol açmıştır. Pseudomonas aeruginosa'da çoğu virülans faktörü ve biyofilm oluşumu, quorum sensing (QS) ile kontrol edilir. QS sisteminin inhibitör moleküller tarafindan inhibisyonu, bakterileri öldürmeye gerek olmayan yeni bir alternatif antivirulens yaklaşımı olarak önerilmiştir. Bu çalı̧̧mada, Prunus avium sapından elde edilen metanol ve aseton özütlerinin $P$. aeruginosa'ya karşı QSI (QS inhibitörleri) ve anti-biyofilm potansiyellerini değerlendirdik. Ekstraktlar 240, 120 ve $60 \mu \mathrm{g} / \mathrm{ml}$ l'ik konsantrasyonlarda test edilmiştir. QS ve biyofilm inhibisyonunu izlemek için lasB-gfp, rhlA-gfp, ve $p q s A$ biyosensör suşları ve $P$. aeruginosa $P A O 1$ kullanıldı. Floresans ve absorbans ölçümleri Cytation 3 çok modlu mikroplaka okuyucu üzerinde gerçekleștirildi. $240 \mu \mathrm{g} / \mathrm{ml}$ konsantrasyonunda aseton özütlerinin las, $r h l$ ve $p q s$ sistemleri üzerine QS ve biyofilm inhibisyon oranları sirasıla $\% 70.43, \% 47.25, \% 76.31$ ve $\% 47.76( \pm 6,60)$ ve metanol özütlerinin sirasiyla $\% 74.96, \% 40.10, \% 71.89$ ve \% $38.54( \pm 3,56)$ olarak kaydedilmiştir. Sonuç olarak, aseton özütlerinin anti-QS ve anti-biyofilm özellikleri metanol özütlerinden daha başarılı olmuştur. $P$. avium'un inhibitör bileşikleri ve bu bileşiklerin insan hücreleri üzerindeki etkilerini keşfetmek için daha fazla araş̧ırmaya ihtiyaç vardır ve daha sonra bu bileşikler yeni ilaç keşiflerinde kullanılabilir.

Anahtar Kelimeler: Pseudomonas aeruginosa, quorum sensing, biyofilm, quorum quenching, Prunus avium stalk, sweet cherry.

\section{INTRODUCTION}

Bacterial pathogenicity is defined as the potential of an organism to cause any disease. As known, the production of virulence factors by microorganisms has great importance in the clinical course of a disease. These factors may cause damages on the host immune system due to failure in the balance between bacterial pathogenicity and host resistance (1). Unfortunately, antibiotics are not sufficiently efficient in the treatment of bacterial infections. Therefore, an antivirulence approach has been proposed to treat infections. By this approach, expressions or 
activities of virulence properties can be prevented and bacteria cannot colonize the host. Furthermore, it has been assumed that there is probably less evolutionary pressure to develop resistant clones than conventional antibiotics because this strategy does not directly kill bacteria but prevent bacterial infections and damages to their host. These anti-virulent drugs can potentially be used in combination with synergistically established or new antimicrobials to prolong the life of these drugs (2, 3).

The World Health Organization (WHO) declared the priorities of antibiotics for pathogens as critical, high, and medium highlighting the need for new antibiotics. According to this list, Pseudomonas aeruginosa is categorized as critical for the discovery of new antibiotics (4). P. aeruginosa can cause nosocomial infections such as cystic fibrosis, especially in immunocompromised patients. In 2004, the U.S. Cystic Fibrosis Foundation Patient Registry reported that $P$. aeruginosa was identified in $57.3 \%$ of all respiratory cultures (5). The data from newborn screening programs showed that the total number of cystic fibrosis $(\mathrm{CF})$ patients in sixteen European countries, $\mathrm{CF}$ adults and CF children in 2025 would rise by $50 \%$, $75 \%, 20 \%$ respectively (6). The clinical importance of this opportunistic pathogen attributed to its resistance to multiple antimicrobial agents, its quorum sensing mediated virulence factors (exoproteases, siderophores, exotoxins and, rhamnolipids, etc.), and ability to form biofilm formation resulting in the community- or hospital-acquired infections (7-9).

Bacteria communicate via quorum sensing system (QS) which allows controlling their social behaviors. A high density of bacterial population in the surrounding environment trigger QS system for intra-species, interspecies, or inter-kingdom interactions $(10,11)$. Autoinducers (AIs), small molecules that can easily diffuse across inner and outer membranes, are secreted into bacterial local milieu. Gram-negative bacteria utilize homoserine lactones (HSLs). It is well documented that $P$. aeruginosa has las, rhl, pqs and iqs systems for interspecies communication (12). Approximately a tenth of the total $P$. aeruginosa genes are coordinated by QS. These genes are responsible for many virulence factors, antibiotic resistance, regulation of metabolic pathways under stress and biofilm structure of $P$. aeruginosa (13). The critical importance of biofilm structures in chronic infections has been emphasized in the literature. Biofilms are sessile community complexes in which bacterial cells attach onto various surfaces in an exopolysaccharide matrix. Biofilm forms are more resistant to antibiotics compared to planktonic forms (14).

Most researchers have focused on an alternative antivirulence approach to combat bacterial antibiotic resistance by disrupting the QS system, called quorum quenching (QQ) (15). In this way, several compounds and enzymes with quorum sensing inhibitory (QSI) potential have been identified to quench the QS mechanism. The criteria for QSI molecules are notified as high specificity, efficiency, stability, having lowmolecular-weight (16).

Since ancient times, different parts of plants have traditionally been used in the treatment of various disorders. Nowadays, they are globally valuable resources of new drugs not only in developing countries but also in modern countries (17). For this reason, compounds with QSI properties are investigated especially in plants and anti-QS potentials of plant species collected from different localities are investigated as direct extracts or based on the substances they contain (18).

Prunus avium L., (sweet cherry) is a member of Rosaceae family and is distributed around the world with a temperate climate but especially in Europe, North Africa, South Australia, New Zealand, USA, Canada, Argentina and Chile $(19,20)$. P. avium has several beneficial effects on various illnesses such as cancer, cardiovascular disease, diabetes, Alzheimer's disease, neurodegenerative diseases and, other inflammatory diseases as well as being consumed as food $(21,22)$. Different parts of $P$. avium such as its fruit, stem, and bark are used for medicinal and therapeutic purposes (20). Furthermore, its antibacterial, antioxidant, and anti-inflammatory activities have been demonstrated (23-29).

To our knowledge, there is no study investigating the QSI and anti-biofilm potentials of $P$. avium stalk against $P$. aeruginosa. In the view of an urgent need for new alternative approaches that can solve the global health problem due to the current antibiotic resistance, the potential impact of $P$. avium (sweet cherry) stalk was investigated to inhibit the QS system and biofilm formation of $P$. aeruginosa. For this purpose, QSI potentials of acetone ad methanol extracts of $P$. avium stalk samples were tested on the biosensor strains of $P$. aeruginosa, lasB-gfp, rhlA-gfp and pqsA-gfp, and antibiofilm activities were tested on the $P A O 1$ wild type strain.

\section{MATERIAL AND METHODS}

\subsection{Sample Collection and Extraction of P. avium Stalk Samples by Acetone and Methanol Solvents}

Following the washing and drying of $P$. avium stalk samples, ten grams of each sample were weighed and pulverized. Acetone and methanol solvents were added into sterile bottles including the samples and stored in a dark place for 3 days. They were evaporated in a rotary evaporator at $40{ }^{\circ} \mathrm{C}$ and $100 \mathrm{rpm}$. The acetone and methanol extracts of $P$. avium stalk samples were weighed again to obtain the weight of crude extracts. To evaluate the anti-QS and anti-biofilm properties, a 
stock concentration of these extracts was prepared as $16 \mathrm{mg} / \mathrm{ml}$ and then dissolved in $100 \%$ DMSO. Finally, these extracts were diluted with a physiological saline solution.

\subsection{Monitor Strains}

lasB-gfp, rhlA-gfp, and $p q s A-g f p$ were used as QS monitor strains of $P$. aeruginosa (30-32). These monitor strains included lasR, rhlR, pqsR regulated promoters and a gene for an unstable green fluorescent protein (gfp). In the present study, M9 minimal media supplemented with $2.5 \mathrm{mg} / \mathrm{l}$ thiamine, $0.5 \%$ (wt/vol) glucose, and $0.5 \%$ (wt/vol) casamino acids were used for the growth of the test bacteria.

\subsection{QSI Screening}

QSI potentials of the acetone and methanol extracts of $P$. avium stalk samples were examined in 96-well black microplates (Nunc, Thermo Scientific) (33). $100 \mu 1$ of the prepared growth medium given above was added to each well. The test extracts were then diluted three-fold to obtain final concentrations of tested extracts as 240 , 120 and $60 \mu \mathrm{g} / \mathrm{ml}$ in 96-well black microplates. The total volume in each well was then adjusted to $200 \mu \mathrm{l}$ by adding overnight cultures of the lasB-gfp, rhlA-gfp and $p q s A-g f p$ monitor strains with an OD $450 \mathrm{~nm}$ of 0.1 . The positive and negative control groups were also tested. The experiments were performed in three replicates. The bacterial growth and gfp expressions were measured every 15 minutes using Cytation 3 multimode microplate reader (Biotek) for $16 \mathrm{~h}$. The measurements of fluorescence were recorded at $485 \mathrm{~nm}$ excitation and $535 \mathrm{~nm}$ emission wavelengths.

\subsection{Biofilm Experiments}

$P$. aeruginosa $P A O 1$ strain was incubated overnight in a prepared M9 growth medium at $37^{\circ} \mathrm{C}$. In 96-well microplates, the acetone and methanol extracts of $P$. avium stalk samples were tested at the concentrations of 240, 120 and $60 \mu \mathrm{g} / \mathrm{ml}$, respectively. The experiments included positive and negative controls. Three replicates were made for the tests. The biofilm forms were stained with $0.1 \%$ crystal violet and measured at OD $590 \mathrm{~nm}$ in the microplate reader (Cytation 3-BioTek).

\section{RESULTS}

Three concentrations (240, 120 and $60 \mu \mathrm{g} / \mathrm{ml})$ of acetone and methanol extracts of $P$. avium stalk samples were tested on lasB-gfp, rhlA-gfp and $p q s A-g f p$ monitor strains of $P$. aeruginosa. Since azithromycin was reported to reduce the transcription of lasI by $80 \%$ and of rhlI by $50 \%$ in the literature (34), azithromycin was also tested as a positive control to inhibit tested QS systems (las, rhl and pqs). We determined that azithromycin was significantly able to inhibit gfp production of tested monitor strains (The data was not shown). In our experiments, maximum QS inhibition ratios on las, rhl and pqs systems were detected at a certain concentration of $240 \mu \mathrm{g} / \mathrm{ml}$ for acetone and methanol extracts of $P$. avium stalk samples. The acetone extracts of $P$. avium stalk at a concentration of $240 \mu \mathrm{g} / \mathrm{ml}$ inhibited las, rhl and pqs systems of $P$. aeruginosa in ratios of $70.43 \%, 47.25 \%$, and $76.31 \%$ respectively. The related dose-response curves of las $B$ gfp, rhlA-gfp and $p q s A-g f p$ monitor strains of $P$. aeruginosa treated with the acetone extracts of $P$. avium stalk at certain concentrations of 240, 120 and 60 $\mu \mathrm{g} / \mathrm{ml}$ were given in Figure 1A-C.

On the other hand, QS inhibitory potentials for las, rhl and pqs systems of methanol extracts of $P$. avium stalk were recorded as $74.96 \%, 40.10 \%$, and $71.89 \%$, respectively Figure 2.

Anti-biofilm properties of acetone and methanol extracts of $P$. avium stalk samples were tested against $P A O 1$ strain. The inhibition percentages for biofilm formation belonging to the extracts of $P$. avium stalk samples at a dose of $240 \mu \mathrm{g} / \mathrm{ml}$ were found to be slightly different and recorded as $47.76 \%( \pm 6.60)$ and $38.54 \%( \pm 3.56)$, respectively. Biofilm inhibition ratios of the acetone and methanol extracts of $P$. avium stalk at the concentrations of 240,120,60 $\mu \mathrm{g} / \mathrm{ml}$ against $P A O 1$ strain were given in Figures 3-4. These results indicate that acetone extracts have a more pronounced effect in comparison to methanol extracts. 

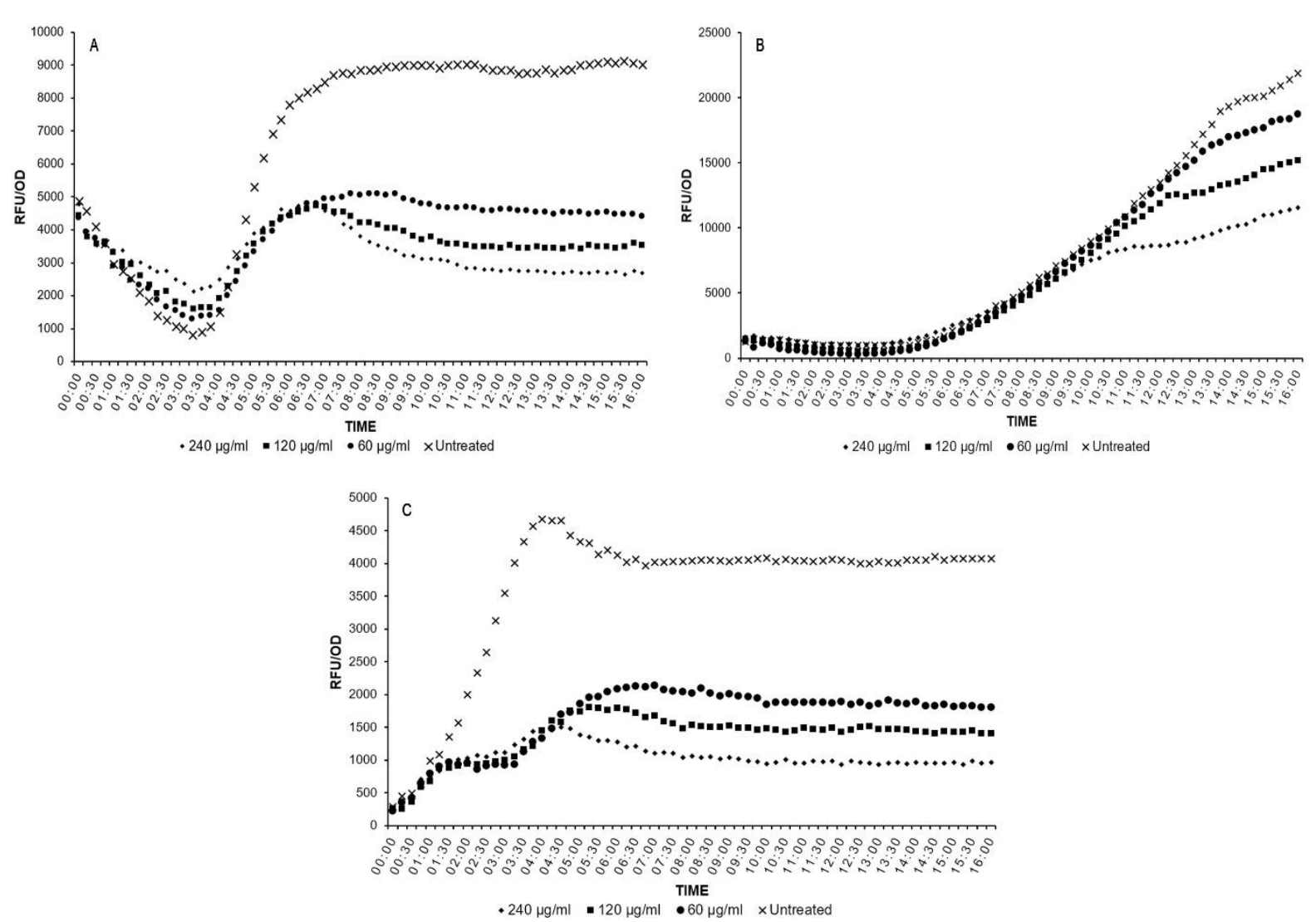

Figure 1. Dose-response curves of biomonitor strains of $P$. aeruginosa treated with the acetone extracts of P.avium stalk at certain concentrations of 240, 120 and $60 \mu \mathrm{g} / \mathrm{ml}$. Data are shown as relative fluorescence unit over OD $450 \mathrm{~nm}$.
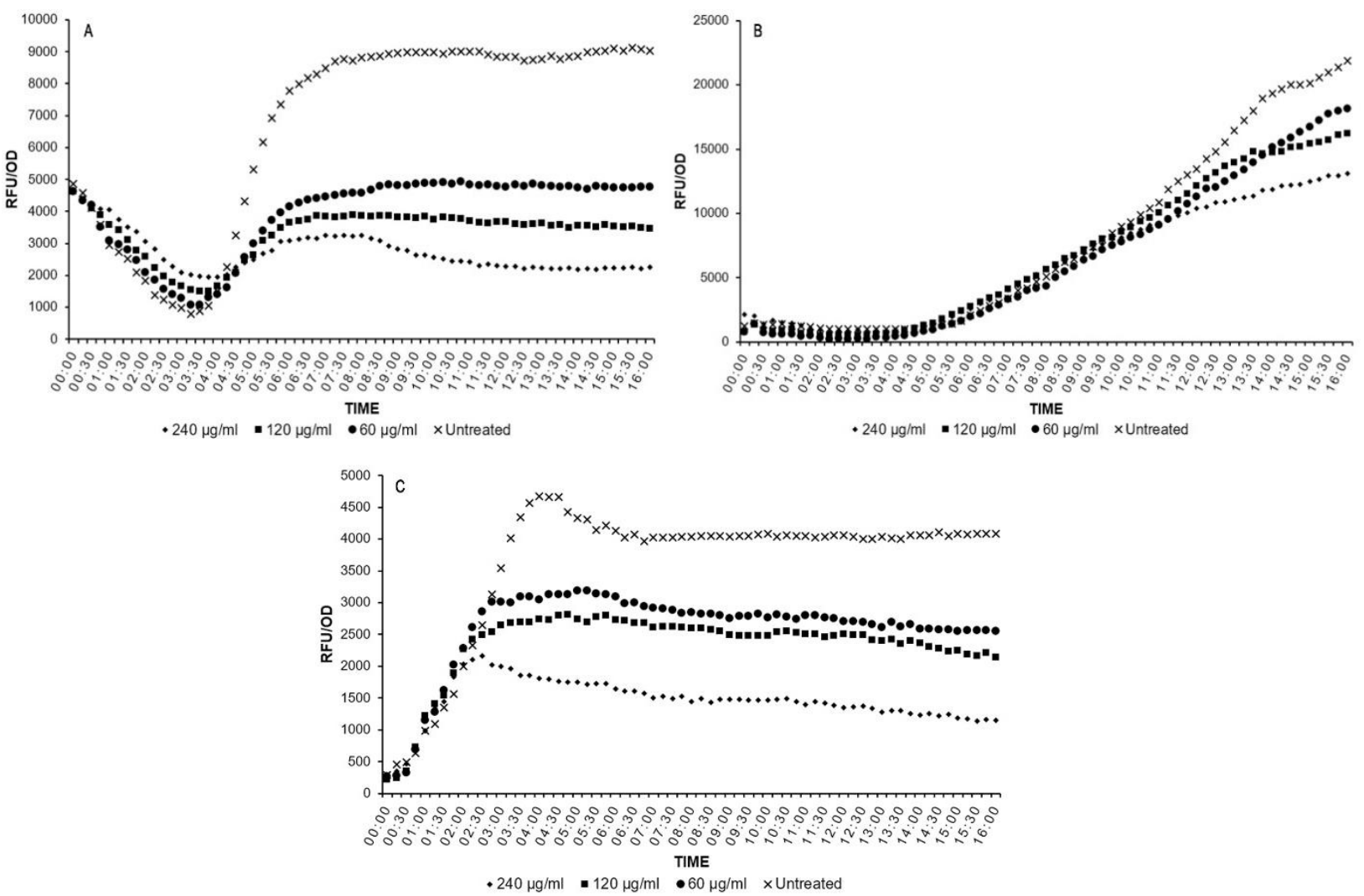

Figure 2. Dose-response curves of biomonitor strains of $P$. aeruginosa treated with the methanol extracts of P.avium stalk at the certain concentrations of 240, 120 and $60 \mu \mathrm{g} / \mathrm{ml}$. Data are shown as relative fluorescence unit over OD $450 \mathrm{~nm}$. 


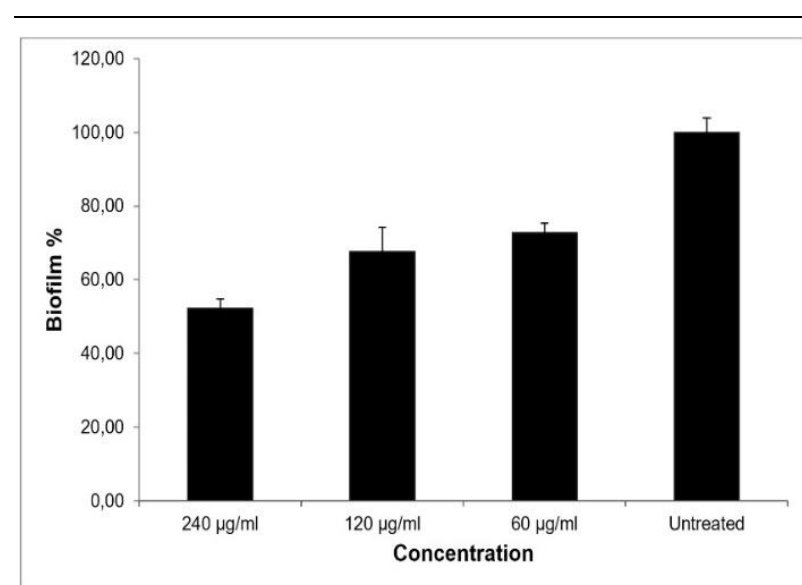

Figure 3. The percentage of anti-biofilm properties of the acetone extracts of $P$.avium stalk at concentrations of $240,120,60 \mu \mathrm{g} / \mathrm{ml}$ against $P A O 1$ strain.

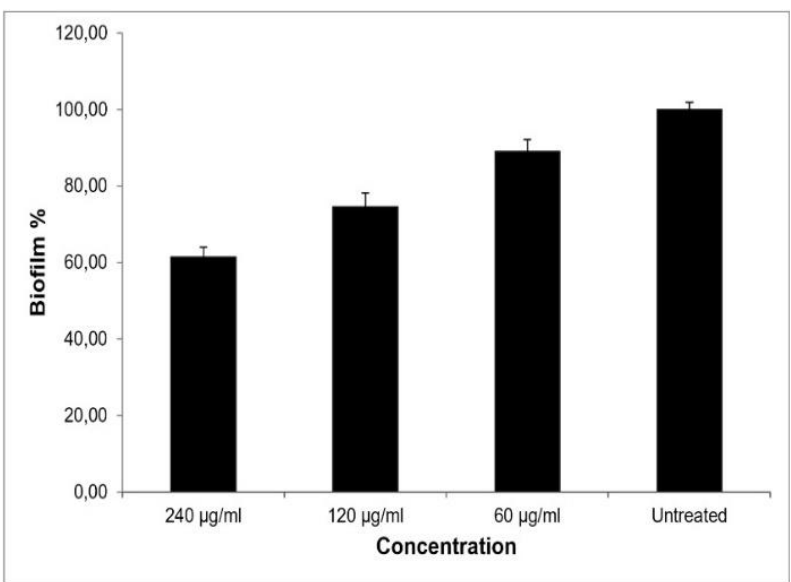

Figure 4. The percentage of anti-biofilm properties of the methanol extracts of P.avium stalk at the concentrations of $240,120,60 \mu \mathrm{g} / \mathrm{ml}$ against $P A O 1$ strain.

\section{DISCUSSION}

As known, antibiotic misuse or overuse led to the problem of antibiotic resistance as a global healthcare problem. $P$. aeruginosa controls its' virulence factors and biofilm formation by QS mechanism. Alternatively, QS system and biofilm formation can be inhibited by inhibitor molecules as an antivirulence approach without killing bacteria. To the best of our knowledge, anti-QS and anti-biofilm effects of $P$. avium stalk samples against $P$. aeruginosa have not been studied yet. In this study, we demonstrated the potential inhibitory properties of acetone and methanol extracts of $P$. avium stalk samples on QS mechanisms and biofilm formation.

It has been well documented that the different parts (fruit, seed, stem bark and roots) of $P$. avium (sweet cherry) has several bioactive compounds (35-39). Several chemical compounds such as flavonoids, phenolics, polyphenols, alkaloids, tannins were reported in $P$. avium $(37,40-42)$. There are many studies in the literature focusing on the antibacterial activities of extracts or fractions of different parts of $P$. avium obtained by different solvents or of its' fruit juice. Rovčanin et al. (2015), reported that ethanol extracts of $P$. avium petiole had an antibacterial effect against multiple antibiotic-resistant Escherichia coli and they detected also high concentrations of phenols and flavonoids in the ethanol extracts (26). Accordingly, the inhibitory activities of leaf and stem bark ethanol extracts of $P$. avium were found to be more effective against Gram-negative compared to the Gram-positive bacteria. In this study, researchers detected that the stem bark extracts were more potent when compared to the leaf extracts (39).

On the other hand, it was demonstrated that ethyl acetate and butanol fractions of $P$. avium had high antibacterial activity against Listeria monocytogenes, Staphylococcus aureus, and Salmonella typhimurium but the extracts and fractions had no inhibitory effect against $P$. aeruginosa (23). Propionibacterium acnes, acne-inducing bacteria, was also inhibited by the juice of $P$. avium. The juice and/or methanol extracts of $P$. avium inhibited the growth of Streptococcus pyogenes and P. acnes but not Staphylococcus epidermidis (24). The reason for differences in the sensitivity of Grampositive and Gram-negative bacteria might be dependent on variables in the pattern including the cell wall such as peptidoglycan structure or high levels of lipopolysaccharides (39). Taken together, P. avium has noticeable antibacterial potentials against Grampositive, or Gram-negative bacteria depending on the species. Nevertheless, studies about the antibacterial properties of $P$. avium against $P$. aeruginosa are scarce. To our knowledge, there is no study investigating the QSI and anti-biofilm potentials of $P$. avium stalk against $P$. aeruginosa. As mentioned before, quorum quenching, by other words quorum sensing inhibition, is a novel approach to overcome bacterial antibiotic resistance. In this meaning, plant-based QSIs with fewer side effects, considerable bioavailability, low costs and no toxicity may serve alternatively promising treatment strategies individually or along with conventional antibiotics. The stalk parts of $P$. avium are generally discarded. The evaluation of stalk parts of this plant that will be disposed may provide highly possible add value to the country's economy since $P$. avium stalk may ensure beneficial effects in terms of health without any cost. Therefore, there are many positive aspects of utilization of $P$. avium stalk in healthcare because they are plant-based material and have cost-effectiveness as well as their potential therapeutic effects. Besides the evaluation of the material to be discarded can be achieved.

Considering the extract concentrations that we applied in our biofilm experiments, we can suggest that all our three concentrations $(240,120$, and $60 \mu \mathrm{g} / \mathrm{ml})$ are considerably low according to other studies testing the anti-biofilm properties of extracts from various plants. For example, Ravichandiran et al. (2013) reported that Melia dubia bark extracts reduced biofilm formation by 
$84 \%$ and QS system by $75 \%$ in E.coli at a concentration of $30 \mathrm{mg} / \mathrm{ml}(43)$. In another study, it was shown that Capparis spinosa extract inhibited biofilm formation of some pathogen Gram-negative bacteria at a concentration of $2 \mathrm{mg} / \mathrm{ml}$ (44). Sandasi et al., demonstrated that Rosmarinus officinalis, Mentha piperita, and Melaleuca alternifolia exhibited antibiofilm activity against Listeria monocytogenes at a 1 $\mathrm{mg} / \mathrm{ml}$ (45). Trentin et al. (2011) tested the antibiofilm properties of several medicinal plants from the Caatinga in Brazil at the concentration of $0.4 \mathrm{mg} / \mathrm{mL}$ and $4.0 \mathrm{mg} / \mathrm{mL}$ against $S$. epidermidis (46).

In other respects, QS inhibition is usually assessed by the detection of AHL-related inhibitory activity based on the violacein pigment production in Chromobacterium violaceum strain CV026, which is unable to synthesize its AHL in the literature. Fluorescence-based biosensor strains have more advantages to evaluate QS response of bacterial cells due to their ability for screening directly QS-related gene expressions. Because we tested our samples on biomonitor strains, we could easily observe the inhibition rates by gene expression levels. According to our results, both extracts of $P$. avium stalk inhibited the las and pqs system but they provided less inhibition on $r h l$ system of $P$. aeruginosa. Anti-biofilm properties of $P$. avium stalk extracts were tested against $P A O 1$ strain. The inhibition percentages for biofilm formation belonging to the acetone and methanol extracts of $P$. avium stalk samples at a concentration of $240 \mu \mathrm{g} / \mathrm{ml}$ were found to be slightly different and recorded as $47.76 \%( \pm 6,60)$ and $38.54 \%( \pm 3,56)$, respectively. Accordingly, to the QS experiments, our acetone extracts were found to be more effective on biofilm inhibition in contrast to methanol extracts.

From this point, taken into consideration of ethnobotanical importance and bioactive potential of $P$. avium stalk, antibiotic resistance problems may be solved by interrupting the QS system as an alternative strategy. Further detailed studies about the bioactive compounds of this plant should be performed. These compounds may be used in the manufacture of new drugs or alternatively in combination with antibiotics in drug discovery.

\section{REFERENCES}

[1] Peterson, J.W. (1996). Bacterial pathogenesis. In Medical microbiology $4^{\text {th }}$ edition, S. Baron (ed.), University of Texas Medical Branch, Galveston.

[2] Rasko, D.A. and Sperandio, V. (2010). Antivirulence strategies to combat bacteria-mediated disease. Nat. Rev. Drug Discov., 9(2): 117-128.

[3] Dickey, S.W., Cheung, G.Y. and Otto, M. (2017). Different drugs for bad bugs: Antivirulence strategies in the age of antibiotic resistance. Nat. Rev. Drug Discov., 16: 457-471.

[4]World Health Organization (2017). Prioritization Pathogens Infographic. http://www.who.int/medicines/prioritizationpathogens-infographic.pdf?ua $=1$.

[5] Driscoll, J.A., Brody, S.L. and Kollef, M.H. (2007). The epidemiology, pathogenesis and treatment of Pseudomonas aeruginosa infections. Drugs, 67: 351-368.

[6] Schwarz, C., Bouchara, J.P., Buzina, W., Chrenkova, V., Dmeńska, H., de la Pedrosa, E.G.G., Canton, R., Fiscarelli, E., Le Govic, Y., Kondori, N., Matos, T., Romanowska, E., Ziesing, S. and Sedlacek, L. (2018). Organization of patient management and fungal epidemiology in cystic fibrosis. Mycopathologia, 183: 7-19.

[7] Singh, P.K., Schaefer, A.L., Parsek, M.R., Moninger, T.O., Welsh, M.J. and Greenberg, E.P. (2000). Quorum-sensing signals indicate that cystic fibrosis lungs are infected with bacterial biofilms. Nature, 407(6805): 762-764.

[8] Smith, R.S. and Iglewski, B.H. (2003). Pseudomonas aeruginosa quorum sensing as a potential antimicrobial target. J. Clin. Invest, 112(10): 1460-1465.

[9] Rasmussen, T.B. and Givskov, M. (2006). Quorumsensing inhibitors as anti-pathogenic drugs. Int. J. Med. Microbiol., 296(2-3): 149-161.

[10] Rutherford, S.T. and Bassler, B.L. (2012). Bacterial quorum sensing: its role in virulence and possibilities for its control. Cold Spring Harb. Perspect. Med., 2(11):a012427.

[11] Khan F., Javaid, A., Kim, Y.M., (2019). Functional diversity of quorum sensing receptors in pathogenic bacteria: Interspecies, intraspecies and interkingdom level. Curr. Drug Targets, 20(6): 655-667.

[12] Lee, J. and Zhang, L. (2015). The hierarchy quorum sensing network in Pseudomonas aeruginosa. Protein \& Cell, 6(1): 26-41.

[13] Moradali, M.F., Ghods, S. and Rehm, B.H. (2017). Pseudomonas aeruginosa lifestyle: a paradigm for adaptation, survival, and persistence. Front. Cell Infect. Microbiol, 7:39.

[14] Olson, M.E., Ceri, H., Morck, D.W., Buret, A.G. and Read, R.R. (2002). Biofilm bacteria: formation and comparative susceptibility to antibiotics. Can. J. Vet. Res., 66(2): 86.

[15] Tang, K. and Zhang, X.H. (2014). Quorum quenching agents: resources for antivirulence therapy. Mar. Drugs, 12: 3245-3282.

[16] Kalia, V.C. (2013). Quorum sensing inhibitors: an overview. Biotechnol. Adv., 31(2):224-245.

[17] Fowler, M.W. (2006). Plants, medicines and man. J. Sci. Food Agric., 86 (12): 1797-1804.

[18] Koh, C.L., Sam, C.K., Yin, W.F., Tan, L., Krishnan. T., Chong. Y. and Chan, K.G. (2013). Plant-derived natural products as sources of antiquorum sensing compounds. Sensors, 13(5): 6217-6228.

[19] Al-Moghrabi, R.S., Abdel-Gaber, A.M. and Rahal, H.T. (2018). A comparative study on the inhibitive effect of Crataegus oxyacantha and 
Prunus avium plant leaf extracts on the corrosion of mild steel in hydrochloric acid solution. Int. J. Ind. Chem., 9(3):255-263.

[20] Ademović, Z., Hodžić, S., Zahirović, Z.H., Husejnagić, D., Džananović, J., Šarić-Kundalić, B. and Suljagić, J. (2017). Phenolic compounds, antioxidant and antimicrobial properties of the wild cherry (Prunus avium L.) stem. Acta Period. Technol., 48: 1-13.

[21] Kim, D.O., Heo, H.J., Kim, Y.J., Yang, H.S. and Lee, C.Y. (2005). Sweet and sour cherry phenolics and their protective effects on neuronal cells. J. Agric. Food Chem., 53(26): 9921-9927.

[22] McCune, L.M., Kubota. C., Stendell-Hollis, N.R. and Thomson, C.A. (2010). Cherries and health: a review. Crit. Rev. Food Sci. Nutr., 51: 1-12.

[23] Ahn, S.M., Ryu, H.Y., Kang, D.K., Jung, I.C. and Sohn, H.Y. (2009). Antimicrobial and antioxidant activity of the fruit of Prunus avium $L$. Microbiology and Biotechnology Letters, 37(4): 371-376.

[24] Ördögh, L. (2010). Antioxidant and antimicrobial activities of fruit juices and pomace extracts against acne-inducing bacteria. Acta Biol. Szeged., 54(1): 45-49.

[25] Hussain, M.A. (2011). Isolation and identification of an anthocyanin compound from cherry fruit (Prunus avium L.) and study of its antibacterial activity. Tikrit Journal of Pure Science, 16(2): 2630.

[26] Rovčanin, B.R., Ćebović, T., Stešević, D., Kekić, D. and Ristić, M. (2015). Antibacterial effect of Herniaria hirsuta, Prunus avium, Rubia tinctorum and Sempervivum tectorum plant extracts on multiple antibiotic resistant Escherichia coli. Bioscience Journal, 31(6): 1852-1861.

[27] Gonçalves, B., Landbo, A.K., Let, M., Silva, A.P., Rosa, E. and Meyer, A.S. (2004). Storage affects the phenolic profiles and antioxidant activities of cherries (Prunus avium L) on human low-density lipoproteins. J. Sci. Food Agr., 84(9): 1013-1020.

[28] Serrano, M., Guillén, F., Martínez-Romero, D., Castillo, S. and Valero, D. (2005). Chemical constituents and antioxidant activity of sweet cherry at different ripening stages. J. Agric. Food Chem., 53(7): 2741-2745.

[29] Zhang, Y., Neogi, T., Chen, C., Chaisson, C., Hunter, D.J. and Choi, H.K. (2012). Cherry consumption and decreased risk of recurrent gout attacks. Arthritis \& Rheumatism, 64(12): 40044011.

[30]Hentzer, M., Riedel, K., Rasmussen, T.B., Heydor n, A., Andersen, J.B., Parsek, M. and Kjelleberg, S. (2002). Inhibition of quorum sensing in Pseudomonas aeruginosa biofilm bacteria by a halogenated furanone compound. Microbiology, 148(1): 87-102.

[31]Yang, L., Barken,K.B., Skindersoe, M.E., Christe nsen, A.B., Givskov, M. and Tolker-Nielsen, T.
(2007). Effects of iron on DNA release and biofilm development by Pseudomonas aeruginosa. Microbiology, 153(5): 1318-1328.

[32]Yang, L., Rybtke, M.T., Jakobsen, T.H., Hentzer, M., Bjarnsholt, T., Givskov, M. and TolkerNielsen T. (2009). Computer-aided identification of recognized drugs as Pseudomonas aeruginosa quorum-sensing inhibitors. Antimicrob. Agents Chemother., 53(6): 2432-2443.

[33] Bjarnsholt, T., Van Gennip, M., Jakobsen, T.H., Christensen, L.D., Jensen, P.Ø. and Givskov, M. (2005). Garlic blocks quorum sensing and promotes rapid clearing of pulmonary Pseudomonas

aeruginosa infections. Microbiology, 151(12): 3873-3880.

[34] Tateda, K., Comte, R., Pechere, J.C., Köhler, T., Yamaguchi, K. and Van Delden C. (2001). Azithromycin inhibits quorum sensing in Pseudomonas aeruginosa. Antimicrob. Agents Chemother., 45(6): 1930-1933.

[35] Di Cagno, R., Surico, R.F., Minervini, G., Rizzello, C.G., Lovino, R., Servili, M, Taticchi, A., Urbani, S. and Gobbett, M. (2011). Exploitation of sweet cherry (Prunus avium L.) puree added of stem infusion through fermentation by selected autochthonous lactic acid bacteria. Food Microbiology, 28: 900-909.

[36] Bursal, E., Köksal, E., Gülçin, İ., Bilsel, G. and Gören, A.C. (2013). Antioxidant activity and polyphenol content of cherry stem (Cerasus avium L.) determined by LC-MS/MS. Food Res. Int., 51(1): 66-74.

[37] Basanta, M.F., Plá, M.F.E., Raffo, M.D., Stortz, C.A. and Rojas, A.M. (2014). Cherry fibers isolated from harvest residues as valuable dietary fiber and functional food ingredients. J. Food Eng., 126: 149-155.

[38] Aires, A., Dias, C., Carvalho, R. and Saavedra, M.J. (2017). Analysis of glycosylated flavonoids extracted from sweet-cherry stems, as antibacterial agents against pathogenic Escherichia coli isolates. Acta Biochim. Pol., 64(2): 265-271.

[39] Oyetayo, A.M. and Bada, S.O. (2017). Phytochemical screening and antibacterial activity of Prunus avium extracts against selected human pathogens. J. Altern. Complement Med., 18.

[40] Duarte, A.P. and Silva, B.M. (2014). Nutritional and phytochemical potential of Prunus avium $L$. In Natural Products: Research Reviews, V.K. Gupta (ed.), Daya Publishing House, India, 185202.

[41] Petković, B., Matoš, S., Gorgi, N. and Kukrić, Z. (2014). Analysis of antioxidant activity of different species of wild cherry (Prunus avium L.). Glo. Adv. Res. J. Agric. Sci ., 3(5): 128-135.

[42] Bastos, C., Barros, L., Dueñas, M., Calhelha, R.C., Queiroz, M.J.R., Santos-Buelga, C. and Ferreira, 
I.C. (2015). Chemical characterisation and bioactive properties of Prunus avium L.: The widely studied fruits and the unexplored stems. Food Chem., 173: 1045-1053.

[43] Ravichandiran, V., Shanmugam, K. and Princy Solomon A. (2013). Screening of SdiA inhibitors from Melia dubia seeds extracts towards the hold back of uropathogenic $E$. coli quorum sensingregulated factors. Medicinal Chemistry, 9(6): 819827.

[44] Abraham, S.V.P.I, Palani, A., Ramaswamy, B.R., Shunmugiah, K.P. and Arumugam, V.R. (2011). Antiquorum sensing and antibiofilm potential of Capparis spinosa. Arch. Med. Res., 42(8): 658-
668.

[45] Sandasi, M., Leonard, C.M. and Viljoen, A.M. (2010). The in vitro antibiofilm activity of selected culinary herbs and medicinal plants against Listeria monocytogenes. Lett. Appl. Microbiol., 50(1): 30-35.

[46] da Silva Trentin, D., Giordani, R.B., Zimmer, K.R., da Silva, A.G., da Silva, M.V., dos Santos Correia, M.T, Baumvol I.J.R. and Macedo A.J. (2011). Potential of medicinal plants from the Brazilian semi-arid region (Caatinga) against Staphylococcus epidermidis planktonic and biofilm lifestyles. J. Ethnopharmacol., 137(1): 327-335. 